\title{
ANALISIS TINGKAT KESULITAN YANG DIALAMI PESERTA DIDIK DALAM PRAKTIKUM BIOLOGI DI SMA
}

\section{STUDENT DIFFICULTIES ANALYSIS IN BIOLOGY LABORATORY PRACTICES IN SENIOR HIGH SCHOOL}

\author{
Baiq Siti Khaerunnisa ${ }^{1}$, Kusmiyati ${ }^{2 *}$, Moh.Liwa Ilhamdi \\ ${ }^{1}$ Mahasiswi Pendidikan Biologi, Jurusan Pendidikan MIPA, FKIP, Universitas Mataram \\ ${ }^{2}$ Program Studi Pendidikan Biologi, Jurusan Pendidikan MIPA, FKIP, \\ Universitas Mataram \\ Email: kusmiyati_fkip@unram.ac.id
}

Diterima: 06 Februari 2019. Disetujui: 12 Maret 2019. Dipublikasikan: 31 Maret 2019

\begin{abstract}
Abstrak: Tujuan penelitian adalah untuk mengetahui kesulitan yang dialami peserta didik dalam praktikum pada mata pelajaran biologi kelas XI IPA di SMA Negeri 1 Kopang, Lombok Tengah, provinsi NTB. Jenis penelitian ini adalah penelitian deskriptif. Populasi dalam penelitian ini yaitu seluruh peserta didik SMA Negeri 1 Kopang yang terdiri dari 552 orang siswa. Teknik pengambilan sampel adalah purposive sampling. Instrumen pengumpulan data yang dugunakan adalah instrumen angkettertutup tipe pilihan ganda. Analisis data dihitung menggunakan rumus persentase tingkat kesulitan dan perbandingan persentase tingkat kesulitan. Hasil analisis data menunjukkan bahwa 76,1\% mengalami kesulitan dengan kategori sulit. Kesimpulan untuk tingkat kesulitan peserta didik dalam praktikum adalah keterampilan, kesiapan, psikologis emosional kebiasaan sikap, kondisi jasmani minat praktikum, ketelitian konsentrasi, pengetahuan materi praktikum dan motivasi peserta didik.
\end{abstract}

Kata Kunci: Tingkat Kesulitan, Praktikum, Biologi.

Abstract: The study aimed to evaluate the student's difficulties in during the laboratory practices for biology subject in grade XI science of SMAN 1 Kopang. The studied populations were all students in 1 Kopang Public High School consisting of 552 students. This study was descriptive research, and use purposive sampling method for data collection. The collected data then calculated with percentages of difficulties level formula and percentages comparison of difficulties level. The result revealed that $76.1 \%$ students experienced difficulty in difficult category. In conclusion, there are several factors which affect the student skills during the lab practices: readiness, psychological, emotional, habit, attitude, interest, physical condition, concentration, student's knowledge and motivation.

Keywords: Biology, Difficulty level, Practice.

PENDAHULUAN
Praktikum merupakan suatu kegiatan yang diselenggarakan oleh pendidik dan dilaksanakan oleh peserta didik, yang bertujuan untuk memberikan pengalaman pada peserta didik, serta dapat membuktikan secara ilmiah tentang teori atau materi yang telah diajarkan oleh pendidik [1-7]. Peserta didik yang berkualitas juga haruslah memiliki pendidik yang berkualitas, sehingga proses belajar mengajar disekolah juga lancar. Namun, pada hakikatnya setiap dari proses pembelajaran terdapat sebuah kesulitan yang dialami oleh peserta didik maupun pendidik yang dapat disebabkan dari faktor ekternal dan faktor internalnya. Kesulitan belajar merupakan suatu kelainan yang mengganggu penderita dalam memahami setiap hal yang ditelaahnya[8-9].

SMA Negeri 1 Kopang merupakan sekolah yang memiliki fasilitas yang cukup memadai, khususnya pada kelengkapan laboratorium yang dimilikinya [10]. Berbagai kesulitan yang dialami peserta didik dapat dilihat dari sifat, motivasi atau kerajinan peserta didik dalam melaksanakan seluruh aktivitas sekolah seperti praktikum. Sebagian besar peserta didik memiliki latar belakang keluarga yang perekonomiannya menengah kebawah, sehingga peserta didik diketahui memiliki kesulitantersendiri dari proses pelaksanaan praktikum khususnya pada saat pengadaan alat dan bahan yang memakai pembiayaan pribadi maupun perkelompok, ataupun kekurangan alat-alat sehingga praktikum tidak terlaksana dengan baik yang seharusnya mampu menunjang kebenaran suatu teori sehingga dapat diaplikasikan oleh peserta didik dalam kehidupan nyatanya.

\section{METODOLOGI PENELITIAN}

Penelitian dilaksanakan pada akhir bulan Juli 2018 hingga awal bulan Agustus 2018 di SMA Negeri 1 Kopang.

\section{Alat dan Bahan}

Alat yang digunakan dalam penelitian ini adalah kertas HVS yang berisi tentang soal-soal angket yang akan dijawab oleh peserta didik. Bahan 
yang digunakan diantaranya adalah pulpen dan alat tulis lain sebagai penunjang dalam menjawab soalsoal yang ada pada angket.

\section{Metode Penelitian}

Jenis penelitian yang digunakan adalah penelitian deskriptif. Statistik

deskriptif dipergunakan untuk mengorganisasikan dan meringkas data numerik yang diperoleh dari hasil pengumpulan data di lapangan [11], [12] berpendapat bahwa data primer merupakan data mentah yang diambil oleh peneliti sendiri (bukan dari orang lain).

\section{Analisis Data}

Muhidin dalam [13] menyebutkan data yang didapat dari lapangan selanjutnya akan di analisis serta di tabulasi dengan rumus persentase yang akurat.Langkah-langkah menganalisis data yaitu menghitung skor angket, menentukan kategori kesulitan, mencari persentase responden serta perbandingan persentase pada masing-masing kategori.

Kategori kesulitanseluruh angket dibagi menjadi 5 kategori yaitu sangat sulit, sulit, kurang sulit, tidak sulit, dan sangat tidak sulit. rentang skor pada masing-masing kategori adalah sebagai berikut (Tabel 2).

Tabel 2. Kategori Tingkat Kesulitan [14].

\begin{tabular}{cl}
\hline Rentang skor & \multicolumn{1}{c}{ Kategori } \\
\hline $45-80$ & Sangat tidak sulit (STS) \\
$81-116$ & Tidak sulit (TS) \\
$117-152$ & Cukup sulit (CS) \\
$153-188$ & Sulit (S) \\
$189-225$ & Sangat sulit (SS) \\
\hline
\end{tabular}

Selanjutnya dicari persentase pada masing-masing kategori kesulitan.

\section{HASIL DAN PEMBAHASAN}

Kesulitan praktikum yang dialami peserta didik kelas XI IPA di SMA Negeri 1 Kopang pada mata pelajaran biologi sebagian besar mengalami kesulitan dengan persentase kategori sulit, yaitu sebesar 76,1\%. Persentase tingkat kesulitan peserta didik paling banyak mengalami masalah kesulitan saat praktikum adalah pada faktor internal, yaitu $19 \%$ pada indikatorketerampilan peserta didik. sedangkan, pada faktor eksternal 12\% berada ditenaga laboran/ beban mengajar guru. Faktor kesulitan yang dihadapi peserta didik seperti psikologis peserta didik (12\%) sering terganggu seperti jarang bersosialisasi, motivasi $(8 \%)$, emosional dan kebiasaan sikap para peserta didik (12\%) yang buruk atau malas juga seringkali menjadi penyebab terjadinya kegagalan selama praktikum, kondisi jasmani peserta didik
(10\%) seperti memiliki cacat, serta minat peserta didik terhadap praktikum $(10 \%)$ yang masih rendah juga dapat ditingkatkan dengan diskusi kelompok. Konsentrasi dan ketelitian (9\%) yang melemah, Penyebab peserta didik mengalami kesulitan karena konsentrasi yang terganggu. Sehingga, guru wajib memberikan motivasi atau dorongan yang dapat meningkatkan konsentrasi peserta didik saat praktikum berlangsung yaitu seperti kenyamanan, dan kedisiplinan dalam ruangan serta mengajarkan peserta didik agar tetap menjaga kebersihan ruangan, alat dan lain sebagainya.

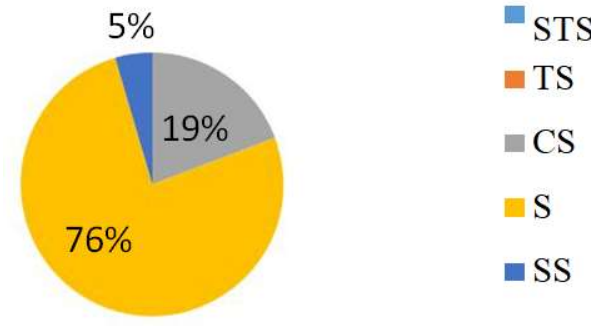

Gambar 1. Diagram Persentase Kesulitan Seluruh Responden

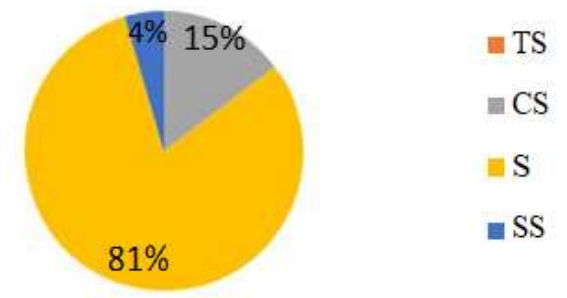

Gambar 2. Diagram Persentase

KesulitanSeluruh Responden Faktor Internal

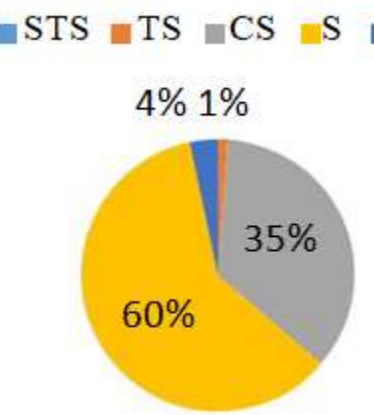

Gambar 3. Diagram Persentase

KesulitanSeluruh Responden Faktor Eksternal

\section{Persentase Kategori Kesulitan Per Indikator}

Berdasarkan hasil analisis data, diketahui peserta didik mengalami kesulitan dengan 5 kategori yang berbeda yaitu kategori sangat tidak sulit (STS), tidak sulit (TS), cukup sulit (CS), sulit (S) dan sangat sulit (SS) dan disusun ke dalam Gambar 4 dan 5. 
- Persentase Kesulitan STS (\%) — Persentase Kesulitan TS (\%) — Persentase Kesulitan CS (\%) Persentase Kesulitan S (\%) • Persentase Kesulitan SS (\%)

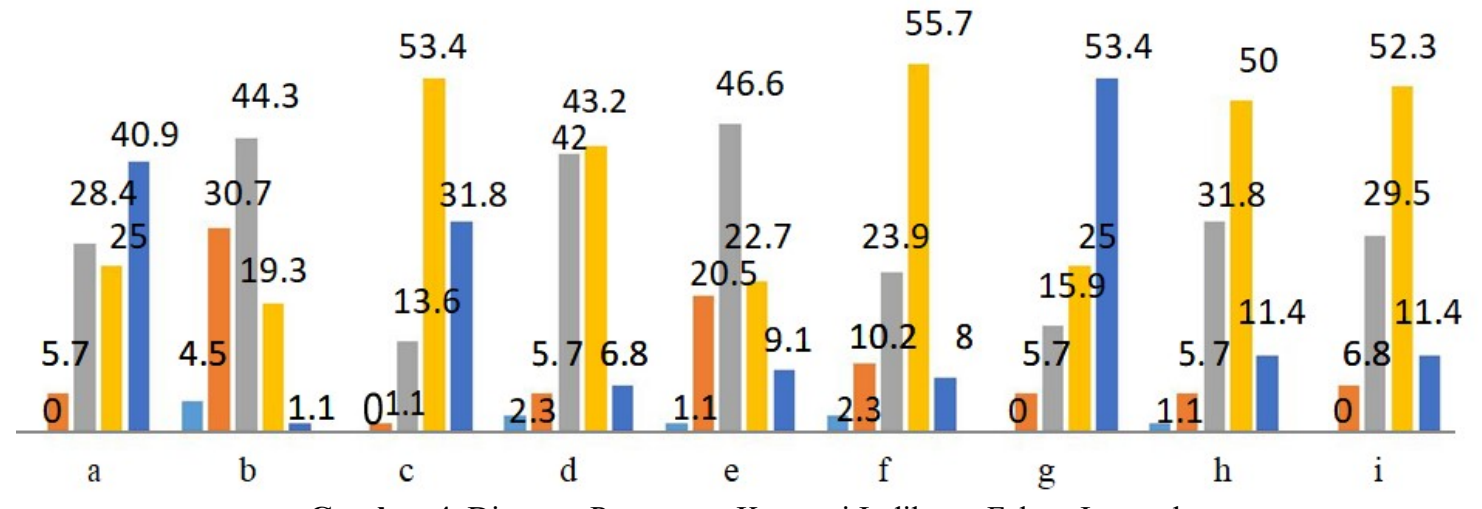

Gambar 4. Diagram Persentase Kategori Indikator Faktor Internal

$$
\begin{aligned}
& \square \text { Persentase Kesulitan STS (\%) } \square \text { Persentase Kesulitan TS (\%) } \\
& \text { Persentase Kesulitan CS (\%) } \square \text { Persentase Kesulitan S (\%) } \\
& \square \text { Persentase Kesulitan SS (\%) }
\end{aligned}
$$

\section{2}

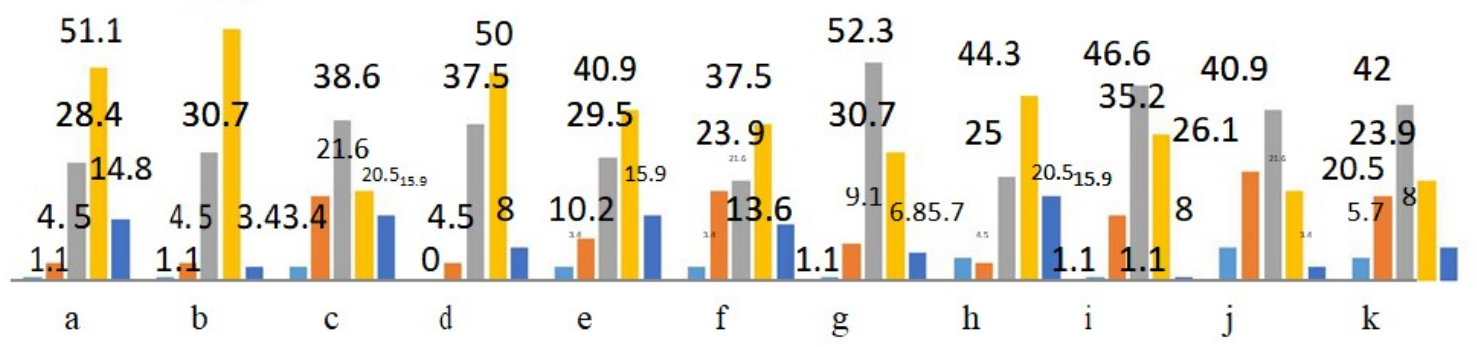

Gambar 5 Diagram Persentase Kategori Indikator Faktor Eksternal

Faktor lain yang menyebabkan peserta didik mengalami kesulitan adalah kemampuan keterampilan (19\%). Hal ini didukung oleh penelitian yang telah dilakukan Krik \& Gallagher, tentang pelatihan penguasaan tugas keterampilan yang ditekankan pada penyerderhanaan dari langkahlangkah atau tugas-tugas keterampilan yang perlu dikuasi individu, sehingga mampu memberi kesempatan pada individu yang bersangkutan untuk lebih berkonsentrasi dalam menguasai materi [15]. Tidak memiliki wawasan yang luas tentang materi praktikum ( $8 \%$ ) serta tidak memiliki buku/ pedoman praktikum (11\%) juga merupakan salah satu faktor yang mempengaruhi peserta didik mengalami berbagai macam kesulitan selama praktikum. Menurut [15], secara khusus, LKS dapat membantu siswa dalam hal: (a). Siswa dapat melakukan praktek dengan mantap karena langkahnya sudah pasti, (b). Siswa tidak akan kehilangan banyak waktu yang seandainya tidak ada buku tersebut harus menerima penjelasan dari guru berkali-kali, dan (c). Buku petunjuk disajikan dalam bentuk tertulis, sehingga dapat diulang untuk dikaji.
Kinerja dan hasil praktikum juga sering dipengaruhi oleh kesiapan siswa (12\%) dalam melakukan kegiatan praktikum. Kesiapan dalam proses praktikum terdiri dari minat peserta didik selama praktikum (10\%), rasa ingin tahu, kemauan, motivasi peserta didik, alatpraktikum (6\%) dan bahan-bahan praktikum (10\%) yang memadai juga sangat mendukung keberhasilan proses praktikum. Tsai dalam [16] menyebutkan kerja kelompok dalam praktikum sesungguhnya bukan hanya bisa mengatasi masalah keterbatasan alat dan bahan, namun juga bisa memfasilitasi siswa untuk belajar, memotivasi, meningkatkan minat belajar.Kerja kelompok dalam praktikum mempunyai beberapa manfaat, maka perlu dipikirkan komposisi anggota kelompok sehingga hasil yang dicapai melalui kerja kelompok bisa maksimal

Keberhasilan selama praktikum juga sangat didukung oleh kemampuan guru (7\%), tenaga laboran dan beban mengajarguru (12\%). Analisis yang dilakukan oleh Hofstein \& Lunetta dalam $\{7\}$, menunjukkan bahwa: (a). Kegiatan praktikum mempunyai potensi istimewa sebagai pengalaman belajar yang dapat meningkatkan hasil belajar siswa; 
(b). Guru memerlukan pengetahuan,keterampilan dan dukungan sumber daya, (c). Guru harus bisa membuat siswa melakukan praktikum yang melibatkan hands-on dan juga minds-on, (d). Persepsi dan tindakan siswa selama praktikum sangat dipengaruhi oleh harapan guru asesmen yang akan diberikan, (e). Guru perlu mengetahui apa yang dipikirkan dan dipelajari siswanya melalui kegiatan praktikum.

\section{Perbandingan Persentase Kesulitan Faktor Internal}

Data Perbandingan persentase kesulitan seluruh responden pada faktor internal disusun pada Gambar 6 dan 7.

$\square$ XI IPA $1 \backsim$ XI IPA 2

$\square$ XI IPA $3 \backsim$ XI IPA 4

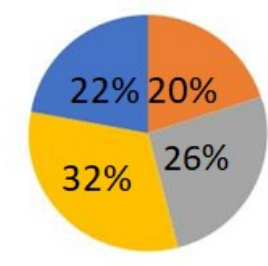

Gambar 6. Diagram Perbandingan PersentaseTingkat Kesulitan Seluruh Responden

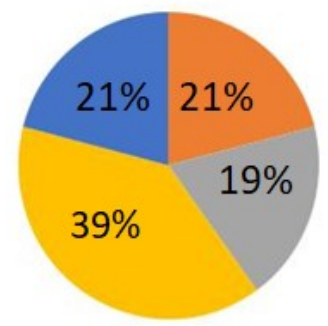

- XI IPA 1

XI IPA 2

XI IPA 3

XI IPA 4

Gambar 7. Diagram Perbandingan Persentase Kesulitan Responden Faktor Internal

\section{Perbandingan Persentase Kesulitan Faktor} Eksternal

Perbandingan persentase kesulitan seluruh responden pada faktor eksternal disusun pada Gambar 8 .

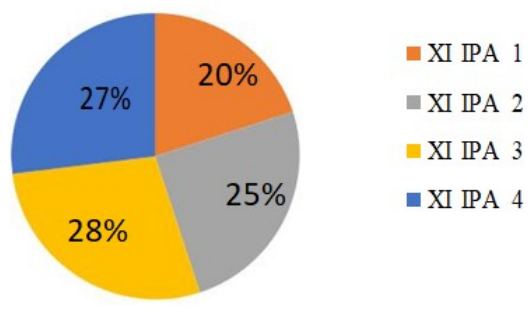

Gambar 8. Diagram Perbandingan PersentaseKesulitan Responden Faktor Eksternal
Perbandingan Persentase Kesulitan Per Indikator Perbandingan persentase kesulitan seluruh responden pada masing-masing indikator faktor internal dan faktor eksternal disusun pada Gambar 9.

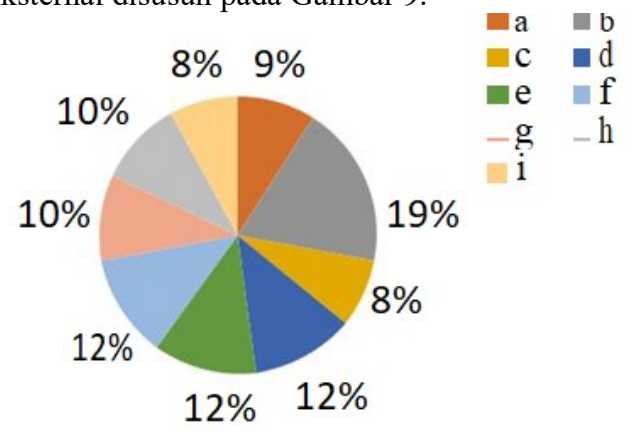

Gambar 9. Diagram Perbandingan

PersentaseKesulitan Indikator Faktor Internal

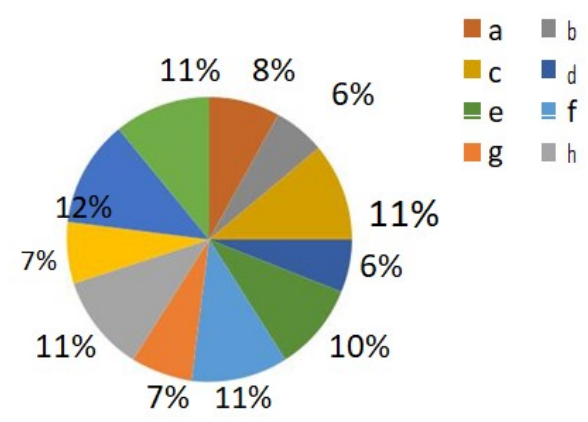

Gambar 10. Diagram Perbandingan

PersentaseKesulitan Indikator Faktor Eksternal

Kesulitan lainnya adalah pemanfaatan alokasi waktu (11\%) yang baik, petunjuk (8\%) serta metode (7\%) praktikum seringkali membingungkan peserta didik. Hodson, 1993; Rustaman et al., 2005 dalam [167] menjelaskan secara garis besar praktikum sering dikaitkan dengan beberapa tujuan: (a). Untuk memotivasi siswa sebab kegiatan praktikum pada umumnya menarik bagi siswa sehingga mereka lebih termotivasi untuk belajar sains; (b). Untuk mengajarkan keterampilan dasar ilmiah; (c). Untuk meningkatkan pemahaman konsep; dan (d). Untuk mengembangkan sikap-sikap ilmiah. Lebih lanjut dijelaskan, kegiatan praktikum dapat dikelompokkan dalam tiga bentuk metode praktikum, yaitu: (a). Bentuk praktikumlatihan, (b). Bentuk praktikum bersifat investigasi (penyelidikan, dan (c). Bentuk praktikum bersifat memberi pengalaman

Kesulitan pembuatan laporan praktikum $(6 \%)$ sering kali dipengaruhi oleh teman bermain peserta didik (11\%). Kesulitan yang sering dialami peserta didik juga terpengaruh dengan faktor lingkungan sekolah (11\%) yang buruk. Djamarah [18], faktorfaktor dari lingkungan sekolah yang dianggap dapat menimbulkan kesulitan peserta didik antara lain : (a). pribadi guru yang kurang baik, (b). guru tidak berkualitas, baik dalam mengambil metode ataupun penguasaan materi, (c).hubungan guru dengan anak 
didik yang kurang harmonis, (d). guru tidak memiliki kecakapan dalam usaha mendiagnosis kesulitan peserta didik, (e).guru menuntut standar pelajaran diatas kemampuan peserta didik, (f). cara guru mengajar yang kurang baik, (g). alat/ media yang kurang memadai, (h). perpustakaan sekolah yang kurang memadai dan kurang merangsang penggunaannya oleh peserta didik, dan lain sebagainya.

Jadi, sebagian besar kesulitan yang dialami peserta didik SMA Negeri 1 Kopang pada tingkatan kategori sulit disebabkan dari faktor internal. Guru yang mampu memberi bimbingan yang tepat kepada peserta didik yang memiliki kesulitan diharapkan mampu meringankan kesulitan yang dialami peserta didik seperti mengarahkan, memberi motivasi, adanya penunjang praktikum sebagai literatur, panduan selama praktikum, suasana belajar yang baik dan kondusif, guru yang penjelasannya sangat mudah dimengerti.

\section{KESIMPULAN DAN SARAN}

\section{Kesimpulan}

Berdasarkan hasil penelitian yang telah dilakukan, maka dapat diambil kesimpulan yaitu:

a. Kesulitan praktikum biologi yang dialami oleh peserta didik SMA Negeri 1 Kopang kelas XI IPA dalam kategori sulit.

b. Faktor kesulitan terbanyak yaitu pada faktor internal meliputi keterampilan, kesiapan, psikologis emosional, kebiasaan sikap, kondisi jasmani, minat praktikum, ketelitian konsentrasi, pengetahuan materi praktikum dan motivasi peserta didik. Sedangkan, pada faktor eksternal yaitu tenaga laboran/ beban mengajar guru, alokasi waktu, teman bermain, buku pedoman, lingkungan sekolah, bahan praktikum, petunjuk praktikum, metode dan kemampuan guru.

Saran

Berdasarkan kesimpulan di atas, maka penulis dapat menyarankan hal-hal sebagai berikut:

a. Guru yang membimbing selama praktikum tetap melakukan pengarahan tentang cara ataupun langkah-langkah penggunaan alat bahan sehingga dapat memberikan motivasi kepada para peserta didik.

b. Guru memberikan pegangan yang dapat memudahkan peserta didik dalam memahami materi praktikum seperti pedoman praktikum, sehingga dapat memberikan pengetahuan yang lebih luas pada peserta didik serta mampu memberikan kejelasan langkah-langkah praktikum apabila ada penjelasan dari guru yang belum dimengerti.

\section{DAFTAR PUSTAKA}

[1] Santosa, P. (2018). Mahir Praktikum Biologi, Penggunaan Alat-Alat Sederhana dan Murah Untuk Percobaan Biologi. Deepublish.
[2] Dewi, I. S., Sunariyati, S., \& Neneng, L. (2016). Analisis Kendala Pelaksanaan Praktikum Biologi di SMA Negeri Se-Kota Palangka Raya. Edu Sains: Jurnal Pendidikan Sains \& Matematika, 2(1).

[3] Maknun, D., Surtikanti, R. H. K., Munandar, A., \& Subahar, S. (2012). Keterampilan esensial dan kompetensi motorik laboratorium mahasiswa calon guru biologi dalam kegiatan praktikum ekologi. Jurnal Pendidikan IPA Indonesia, 1(2).

[4] Bahri, S., Sedijani, P., Zulkifli, L., \& Mertha, I. G. (2018). Pelatihan Pemeliharaan dan Penggunaan Drosophila Sebagai Bahan Praktikum Pada Guru Biologi SMA Di Lombok Barat. Jurnal Pengabdian Magister Pendidikan IPA, 1(1).

[5] Yasmin, N., Ramdani, A., \& Azizah, A. (2015). Pengaruh metode inkuiri terbimbing terhadap keterampilan proses sains dan hasil belajar biologi siswa kelas VIII di SMPN 3 Gunungsari tahun ajaran 2013/2014. Jurnal pijar MIPA, 10(2).

[6] Junaidi, E., Hadisaputra, S., \& Al Idrus, S. W. (2018). Kajian Pelaksanaan Praktikum Kimia Di Sekolah Menengah Atas Di Kabupaten Lombok Barat Indonesia. Jurnal Pijar Mipa, 13(1), 24-31.

[7] Hadisaputra, S., Savalas, L. R. T., \& Hamdiani, S. (2017). Praktikum Kimia Berbasis Kimia Komputasi Untuk Sekolah Menengah Atas. Jurnal Pijar Mipa, 12(1).

[8] Jeranah, J., Nur, S., \& Nurmiati, N. (2018). Faktor-faktor yang mempengaruhi kesulitan dan minat belajar mahasiswa jurusan pendidikan biologi universitas sulawesi barat. SAINTIFIK, 1(2), 87-94.

[9] Ardiansyah, M. (2018). Analisis Kesulitan Belajar Pada Materi Pokok Sistem Ekskresi Manusia di MAN 4 Medan TP 2016/2017(Doctoral dissertation, UNIMED).

[10] Junaidi, E., Hadisaputra, S., \& Al Idrus, S. W. (2017). Kajian Pelaksanaan Praktikum Kimia Di Sekolah Menengah Atas Negeri Se Kabupaten Lombok Tengah. Jurnal Ilmiah Profesi Pendidikan, 2(1).

[11] Soepeno, Bambang. 2002.Statistik terapan dalam Penelitian Ilmu-ilmuSosial dan Pendidikan.Jakarta. Rineka Cipta

[12] Juliadi, Azuar. 2014. Metode penelitian bisnis konsep dan aplikasi. Medan:UMSU press

[13] Yusni, Ahmad. 2006. Kesulitan-kesulitanyang dialami Oleh Siswa Kelas II IPA SMA Negeri 1 Terara dalam Pelakasanaan Praktikum Biologi. Skripsi. Mataram: UNRAM. Pada tanggal 7 Maret 2018, pukul 12:45 WITA

[14] Hadi, Amirul dan Haryono. 2005. Metodologi Penelitian endidikan.Bandung: CV.Pustaka Setia 
J. Pijar MIPA, Vol. 14 No.1, Maret 2019: 23-28

[15] Jamaris, Martini. 2014. Kesulitan Belajar. Jakarta : Ghalia Indonesia

[16] Arikunto,Suharsini. 2010. Prosedur PenelitianSuatu PendekatanPraktik. Jakarta: PT.Rineka Cipta.

[17] Widodo, A. \& Ramdhaningsih, V. (2006). Analisis kegiatan praktikum biologi dengan menggunakan video. JurnalSkripsi. Metalogika. 9(2), 146-158.148.

[18] Djamarah, Syaiful Bahri. 2015. PsikologiBelajar. Jakarta: PT. Rineka Cipta 